\title{
Factors affecting business lending of regional development banks in Indonesia
}

\author{
R.C. Hapsari \& D.A. Chalid \\ Department of Management, Faculty of Economics and Business, Universitas Indonesia, \\ Depok, Indonesia
}

\begin{abstract}
Despite the main role of the Regional Development Bank (RDB), which is to increase the economic activity in each area, it is found that most Regional Development Banks in Indonesia distribute more consumer loans than business ones. This study aims to analyse several factors affecting both the business lending activity in general and the productive loans of the RDB. Using the panel random effect model, this research analysed 26 RDBs from 2001 until 2014. The result shows the differences in the variables affecting business lending activity between general and productive loans. The most prominent result obtained from this study is that regional productivity influences the lending of productive loans but not general loans. This means that, even though the role of the RDB in Indonesia as an agent of regional development is still limited, regional productivity can be used as a key factor to increase productive loans.
\end{abstract}

\section{INTRODUCTION}

Local government banks (BPD) perform the same function as private banks, which is to connect between the surplus units that need more money for their investment activity and the deficit units that have excess money. Law No. 13 of 1963 about the Basic Provisions of Local Government Banks presents another BPD function, which is to assist regional development by providing financing that is in line with the Pembangunan Nasional Semesta Berencana (National Development Planning) framework.

An overview comparison between the total loans disbursed by the BPD and by the other types of commercial banks that were operating in Indonesia at the end of 2014 confirm that the BPDs have low lending performances (see Table 1).

One reason why the BPDs' lending volumes are small compared to the other types of banks may be due to the placement of local government funds as the major resource of BPD financing, which are mostly deposited in the Bank of Indonesia (BI) in the form of SBI. The liquidity and profitability issues become the main reason considered by the local government. On the other hand, BPDs have limited access to household consumers, due to a market share that is smaller than that of private and state banks, even though they have greater access to local people.

Table 1. Total BPD and other bank lending in 2014 (in millions rupiah).

\begin{tabular}{ll}
\hline Bank type & Total lending \\
\hline Private Bank & $1,481,808$ \\
State-Owned Bank & $1,325,087$ \\
Local Government-Owned Bank & 301,456 \\
Foreign Bank & 244,031 \\
Mixed Bank & 195,925 \\
Others & 126,001 \\
\hline
\end{tabular}

Source: SPI Data 2010-2014. 
Pratama (2010) and Oka et al. (2015) found that the increasing DPK owned by the BPDs affected the increase in lending amounts that are distributed to deficit units. Both studies concluded that DPK had a positive influence on bank lending. In other words, the greater the DPK compiled, the more credit that can be disbursed by banks.

In addition, there are other variables that influence the level of bank lending. According to Agustine (2009), credit offers made by commercial banks are influenced by internal and external factors. In the research, the internal factors are represented by the Capital Adequacy Ratio (CAR), Third Party Fund (DPK), Non-Performing Loan (NPL) and Return on Assets (ROA), while external factors affecting the loan portfolio are represented by the interest rate of Bank Indonesia Certificates (SBI).

The BPD lending issues addressed by Indonesia Financial Services Authority (IFSA) are dominated by the lending for the consumption sector rather than for the productive sector, such as working capital and investment. It is a fact that the increase in the BPD's lending from 2010 to 2014 was caused by increasing amounts of consumer lending (see Table 2).

Indonesian Banking Booklet (IBB) (2014) mentioned that the BPDs' lending in the productive sector is still not optimal in terms of lending. The BPDs' lending activity is considered to not be in line with the BPDs' function as an agent of regional development.

As one type of bank in Indonesia, BPDs should have similarities with the other banks concerning lending. However, researchers believe that there are other factors that can affect the level of lending in BPDs. Factors that describe regional economic conditions are considered as the other factors affecting lending, especially productive credit, which is presented by nonoil imports, Gross Domestic Product (GDP) and revenue (PAD) variables.

Total non-oil imports that can be produced by a region describe the size of the level of consumption by the community in an area. When consumption activities are carried out in large

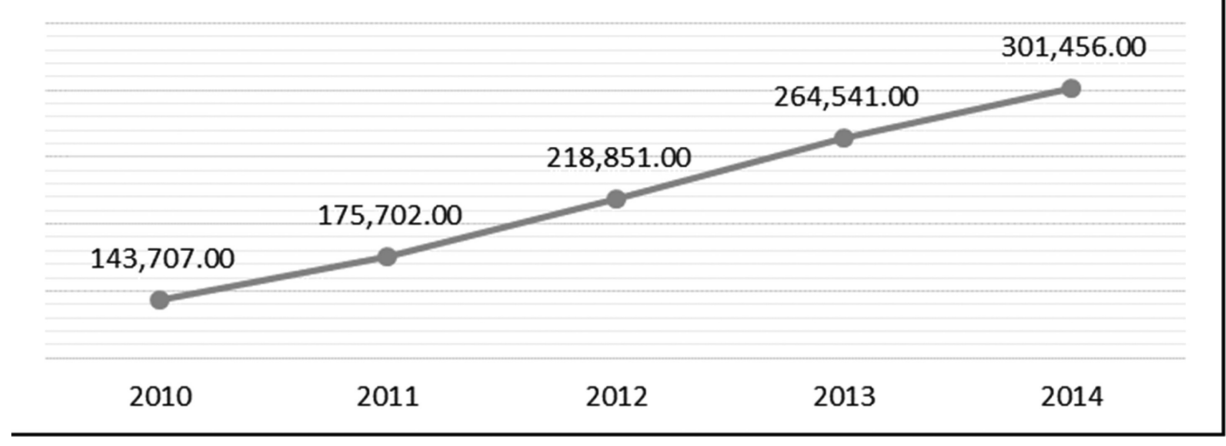

Graph 1. Total BPD lending in 2010-2014 (in million rupiah).

Source: SPI Data 2010-2014.

Table 2. Productive and consumptive lending in 2010-2014.

\begin{tabular}{llll}
\hline & & \multicolumn{2}{l}{ Loan proportion $(\%)$} \\
\cline { 3 - 4 } Year & Total loan & Productive & Consumption \\
\hline 2010 & $140,391.78$ & 36.61 & 65.54 \\
2011 & $170,816.54$ & 34.48 & 67.80 \\
2012 & $212,296.07$ & 20.54 & 67.67 \\
2013 & $234,680.75$ & 31.15 & 68.85 \\
2014 & $269,836.63$ & 30.70 & 69.30 \\
\hline
\end{tabular}

Source: SPI Data 2010-2014. 
numbers, the possibility of filing bank credit as capital for the purchase of imported goods will increase. This is what causes the BPD credit channel, especially productive credit, not to run optimally.

The amount of the Gross Regional Domestic Product (GRDP) generated in a region indicates the level of productivity of the people in the area. If a higher amount of GRDP is generated, this will have an increasingly positive impact on the economic situation in a region. BPDs, which are located in every province in Indonesia, should be more aware of the economic potential of their area. Therefore, it can be said that the BPD will extend more credit, especially productive credit, in the local area, which is shown by the dramatic increase in the GRDP.

Local Revenue (PAD) is revenue that is generated by the production sectors in every province. The total PAD generated by the local government will largely be placed in the banking sector. These funds can be used to help finance the productive sectors. Therefore, the increase in PAD owned by a region is expected to increase lending, especially productive credit, by the BPD.

In addition, bank size, which is proxied by total banking assets, is also one of the factors that can determine the BPDs' lending. According to Indiapsari (2012), the greater the amount of total assets generated by the bank will lead to an increase in the level of loans extended. BPD, as one type of bank in Indonesia, should have similar characteristics to other types of banking. Therefore, if a greater amount of total assets is produced by the BPD, this will increase the level of credit lines from the BPD.

Therefore, based on the description above, this study will examine the effect of some variables, such as non-oil imports, GRDP, PAD, ROA, CAR, NPL, DPK, size and lending rates, in order to investigate total lending and productive lending from the BPD. This is due to BPD's lending are still not productive yet There are also problems that make the BPD unproductive in improving local development by consumption lending.

\section{LITERATURE REVIEW}

\subsection{Previous research}

Several studies have found some related factors that affect bank lending. Agustine (2009) conducted research on internal and external factors that could affect the bank's SME credit supply in four types of commercial banks operating in Indonesia, such as the stateowned banks, national private banks, BPD and foreign mix banks. The variables used in the study were CAR, DPK, ROA and SBI. The study asserted that each variable has different levels of significance in each of the banks studied. In the state-owned banks, the variables that significantly influenced the MSME lending were CAR, DPK and SBI. In the national private banks, SME lending was influenced significantly by the DPK and ROA. MSME lending in the BPD was influenced significantly by the CAR and ROA. Meanwhile, in the foreign banks and mix, SME lending was influenced significantly by the CAR, NPL and SBI.

Another research was conducted by Giovanny (2014) to observe the effects of DPK and CAR during the period 2008-2012. The results of this study suggested that DPK and LDR had a positive and significant impact on lending by the BPD, while CAR, NPL and ROA left a negative and significant impact on lending by the BPD.

Meydianawathi (2007) also conducted research on the effects of DPK, CAR, ROA and the NPL on investment credit and working capital at commercial banks, especially in the SME sector. The results showed that the DPK, ROA and CAR had a positive and significant impact on the supply of credit and working capital investment by commercial banks to the SME sector. Meanwhile, the NPL had a negative and significant effect on the supply of credit to the SME sector.

In Bali, Yoga and Yuliarmi (2013) conducted a study on the factors that influence their loan portfolio, as one source of financing for the SME sector. These factors were DPK, GRDP, interest rates on loans and NPL. The results of the study suggested that DPK had 
a positive effect, while loan interest rates had a negative influence, and the two variables significantly affected credit. Variable GRDP and NPL did not affect their loan portfolio significantly in the province of Bali.

Tomak (2013) conducted a similar study on public and private banks in Turkey. The study aimed to analyse the effect of bank level (size and access to funds) and the market (interest rates, inflation and GDP) on the behaviour of lending in 2003 to 2012. The study concluded that bank lending in Turkey was very dependent on the size of the bank, total liabilities, NPL and the rate of inflation.

Guizani (2014) suggested in his research that bank which has a good health assets capitalization will increase its loans. In addition, the influence of macroeconomic factors could also affect bank lending. However, both of these were temporary because they were influenced by the regional regulations in Tunisia.

In this study, the research is aimed at the BPDs in Indonesia. The financial ratios of banks and lending rates are used as an option to find the factors affecting the level of lending in BPDs. In addition, there are other variables used in this study, such as non-oil imports, GRDP, PAD and the bank size (size). These variables are used in order to see the potential effects of the local economic and financial conditions on the BPDs' lending by considering the BPDs' function as regional development agents. This study will also discuss how these factors may affect the distribution of productive credit by determining the factors that are likely to increase productive lending by the BPDs. Several of the literature reviews used to construct the model are attached in Appendix A.

\section{RESEARCH METHODS}

This research is an empirical study using the BPDs in Indonesia as research objects. This study uses a panel data model and the data was obtained from various sources - secondary data-which provides the information required for the research. The website of each BPD, BI, BPS, IFSA and several other sources are used to obtain the data that are considered relevant to this study. The data used comprises the period from 2001 to 2014.

\subsection{Research model}

Multiple linear regression is a method that will be used to process the data in this study (see Figure 1). This method is used to test the influence of imports, GRDP, PAD, ROA, CAR, NPL, DPK, bank size and lending rates proxy variables to lending, as a whole, and productive lending in Indonesian BPDs. The multiple regression models are shown in the following equations:

$$
\begin{aligned}
& \text { Kredit }_{\text {it }}=\alpha+\beta_{1} \text { Impor }_{\text {it }}+\beta_{2} \text { GRDP }_{\text {it }+} \beta_{3} \text { PAD }_{\text {it }+} \beta_{4} \mathrm{ROA}_{\text {it }}+\beta_{5} \mathrm{CAR}_{\mathrm{it}} \\
& +\beta_{6} \mathrm{NPL}_{\mathrm{it}}+\beta_{7} \mathrm{DPK}_{\mathrm{it}}+\beta_{8} \text { Size }_{\mathrm{it}+} \beta_{9} \text { Sbkredit }_{\mathrm{it}+} \mathrm{e} \ldots \text {. } \\
& \mathrm{KProd}_{i \mathrm{it}}=\alpha+\beta_{1} \mathrm{Impor}_{\mathrm{it}}+\beta_{2} \mathrm{GRDP}_{\mathrm{it}+} \beta_{3} \mathrm{PAD}_{\mathrm{it}+} \beta_{4} \mathrm{ROA}_{\mathrm{it}}+\beta_{5} \mathrm{CAR}_{\mathrm{it}} \\
& +\beta_{6} \mathrm{NPL}_{\mathrm{it}}+\beta_{7} \mathrm{DPK}_{\mathrm{it}}+\beta_{8} \text { Size }_{\mathrm{it}+} \beta_{9} \text { Sbkredit }_{\mathrm{it}+} \mathrm{e} \ldots \ldots
\end{aligned}
$$

\begin{tabular}{|c|c|c|c|}
\hline Kredit $_{i t}$ & Total Loan & $\mathrm{NPL}_{\mathrm{it}}$ & Non-Performing Loan \\
\hline $\operatorname{KProd}_{\mathrm{it}}$ & Total Productive Loan & $\mathrm{DPK}_{\mathrm{it}}$ & Third Party Funds \\
\hline & Constanta & Size $_{i t}$ & Total Asset \\
\hline Impor $_{\text {it }}$ & Non-Oil and Gas Import & Sbkredit $_{\text {it }}$ & Interest Rate \\
\hline GRDP $_{\text {it }}$ & Gross Regional Domestic Product & $\beta_{1} \ldots \beta_{9}$ & Coef.Var. $\mathrm{X}_{1} \ldots \mathrm{X}_{9}$ \\
\hline $\mathrm{PAD}_{\text {it }}$ & Regional Income & $\mathrm{e}$ & Error \\
\hline $\mathrm{ROA}_{\mathrm{it}}$ & Return on Asset & $\mathrm{i}$ & Cross Section Term \\
\hline $\mathrm{CAR}_{\text {it }}$ & Capital Adequacy Ratio & $\mathrm{t}$ & Observation Period \\
\hline
\end{tabular}

where: 


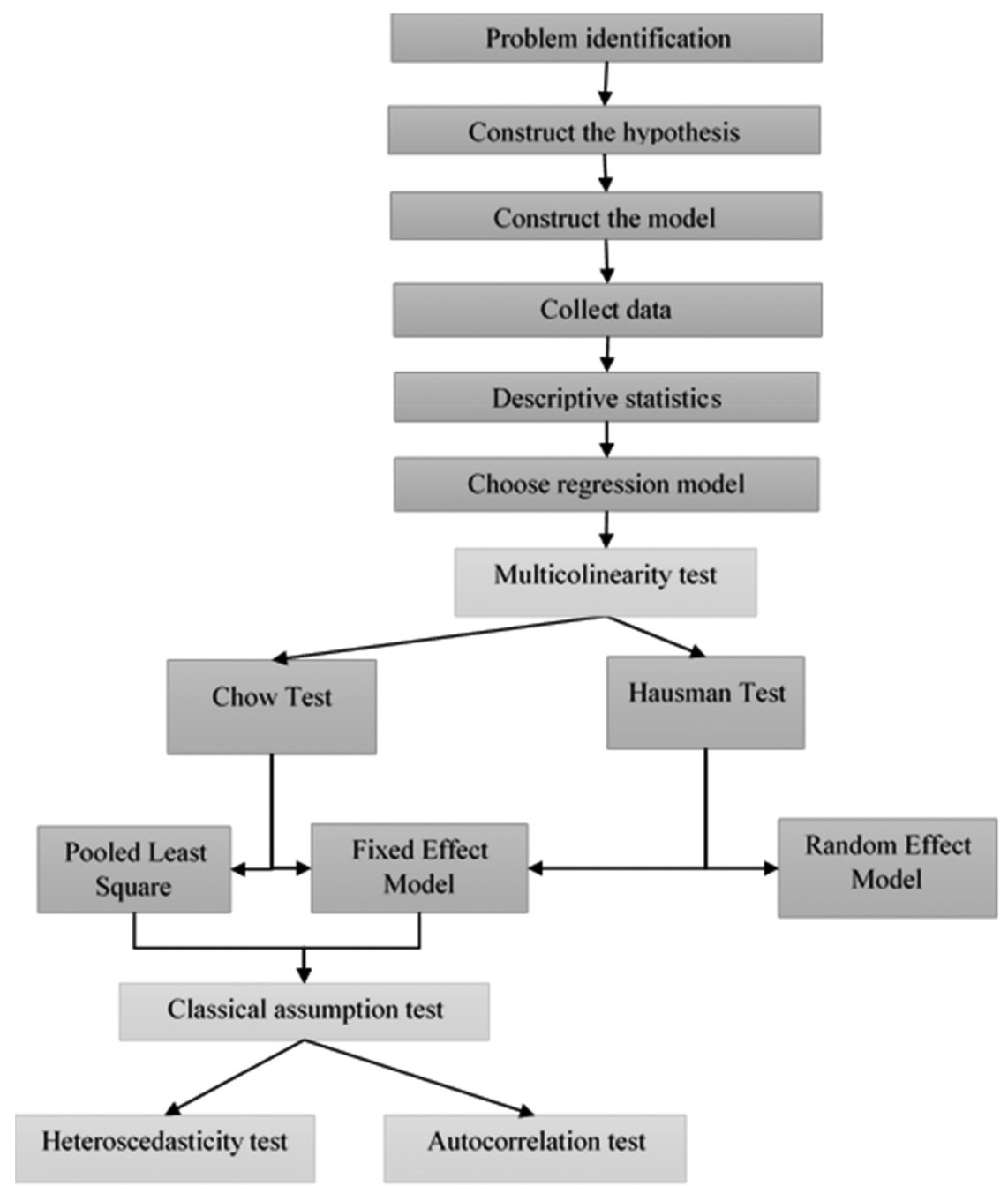

Figure 1. Research scheme.

Source: Author (2016).

The regression estimation uses two different methods, the Fixed Effects Model (FEM) and the Random Effects Model (REM). Furthermore, the regression coefficients obtained are tested with $\mathrm{v}$ regression coefficient ( $\mathrm{t}$-test) and model regression coefficient ( $\mathrm{F}$ test). In addition, a classic assumption test is conducted to ensure that the model fits the Best Linear Unbiased Estimator (BLUE) criteria in linear regression.

\section{RESULT AND DISCUSSION}

Before regressing the model, the researcher carried out the model selection test to select the correct model that can be used between the fixed effect model, random effect model or pooled least square. The result is shown in Table 3. Thereafter, the researcher did the classical assumption tests, namely the heteroscedasticity test, autocorrelation test and multicollinearity test, the results of which are shown in Table 3 below. 
From the table below, the researcher used the fixed effect model for Equation 1 and the random effect model for Equation 2. Since there were some classical assumption problems, the researcher also used robust coefficient correction. The final result of the regression is shown in Table 5.

Table 3. Model selection test.

(1)

\begin{tabular}{|c|c|c|c|c|c|}
\hline \multirow[b]{3}{*}{ Test } & \multirow[b]{3}{*}{ Hypothesis } & \multirow{2}{*}{\multicolumn{2}{|c|}{ Total loan }} & \multirow{2}{*}{\multicolumn{2}{|c|}{ Total productive loan }} \\
\hline & & & & & \\
\hline & & Result & Model selection & Result & $\begin{array}{l}\text { Model } \\
\text { selection }\end{array}$ \\
\hline Chow test & $\begin{array}{l}\mathrm{H}_{0}: \mathrm{PLS} \\
\mathrm{H}_{1}: \mathrm{FE}\end{array}$ & Reject $\mathrm{H}_{0}$ & FE & Reject $\mathrm{H}_{0}$ & $\mathrm{FE}$ \\
\hline Hausman test & $\begin{array}{l}\mathrm{H}_{0}: \mathrm{RE} \\
\mathrm{H}_{1}: \mathrm{FE}\end{array}$ & Reject $\mathrm{H}_{0}$ & $\mathrm{FE}$ & Not Reject $\mathrm{H}_{0}$ & RE \\
\hline
\end{tabular}

Source: Author (2016).

Table 4. The result of BLUE test.

\begin{tabular}{lllll}
\hline & & \multicolumn{2}{l}{ Blue test } & \\
\cline { 3 - 5 } Equation & Model selected & Multicollinearity & Heteroscedasticity & Autocorrelation \\
\hline$(1)$ & FE & V & v & v \\
$(2)$ & RE & V & - & - \\
\hline
\end{tabular}

Source: Author (2016).

Table 5. Regression results in Equation 1 and Equation 2.

\begin{tabular}{|c|c|c|c|c|}
\hline \multirow{3}{*}{$\underbrace{\text { Variable }}_{\text {Dependent }}$} & \multirow{2}{*}{\multicolumn{2}{|c|}{$\begin{array}{l}\text { Equation } 1 \\
\text { Total loan }\end{array}$}} & \multirow{2}{*}{\multicolumn{2}{|c|}{$\frac{\text { Equation } 2}{\text { Total productive loan }}$}} \\
\hline & & & & \\
\hline & Coefficient & $\begin{array}{l}\text { Probability } \\
\text { value }\end{array}$ & Coefficient & $\begin{array}{l}\text { Probability } \\
\text { value }\end{array}$ \\
\hline Non-Oil and Gas Import & -0.010 & $0.071^{*}$ & 0.021 & 0.447 \\
\hline GRDP & 0.023 & 0.626 & 0.103 & $0.035^{* *}$ \\
\hline PAD & 0.308 & $0.000^{* * *}$ & -0.098 & 0.718 \\
\hline ROA & 0.003 & 0.879 & 0.079 & 0.457 \\
\hline CAR & -0.012 & $0.002^{* * *}$ & -0.032 & $0.008 * * *$ \\
\hline NPL & -0.003 & $0.069^{*}$ & 0.020 & 0.595 \\
\hline DPK & -0.072 & 0.226 & 0.294 & $0.093^{*}$ \\
\hline SIZE & 0.608 & $0.000^{* * *}$ & 0.987 & $0.002^{* * *}$ \\
\hline Interest Rate & -0.169 & $0.000 * * *$ & 0.066 & 0.473 \\
\hline Constant & 4.507 & 0.003 & -7.011 & 0.043 \\
\hline $\mathrm{R}^{2}$ & 0.9598 & & 0.7178 & \\
\hline Prob > F / chi 2 & 0.0000 & & 0.0000 & \\
\hline
\end{tabular}

Source: Author (2016). 


\subsection{Equation model (1)}

In the equation model (1), the BPDs' loan distribution depends on some variables, such as:

Non-oil and gas imports have a negative impact on the BPDs' lending distribution, suggesting that high non-oil and gas imports imply a smaller lending distribution. Credit reduction in the consumption sector is supported by the BRC programme (BPD Regional Champion), which serves to push the BPD to be more active in increasing lending to the productive sectors (Indonesian Banking Booklet 2014). Therefore, any increase in the imports of non-oil and gas in an area will reduce the BPD's lending rate as well as the BPDs' commitment to promote regional development.

The PAD variable is positively associated with BPD lending. The increase in the number of PAD will increase the amount of lending of the BPD in the region. According to Yuwono \& Warsito (2001) in Pangastuti (2015), PAD is local revenue collected by local governments, which is normally placed in the BPD by the local governments (Parwito, 2015). This is because the governments fear that the BPD will fail to repay their money which is funded for projects or potential business in the region. That condition ensures that almost $60 \%$ of the deposits owned by the BPD come from funds belonging to the local government. Greater lending to the public, especially in the productive sector, is expected to stimulate regional economic growth (Rokhim, 2007).

However, considering that PAD funds placed at the BPD are only temporary, even though the nominal amount is large enough, the BPD is reluctant to channel PAD in the form of lending allowance. Therefore, many BPDs in Indonesia wait for PAD from the local government revenue rather than maximising their own capital and deposits to conduct banking activities. This then makes the placement of funds in the BPD very important, since most of the BPD capital for lending to the public comes from the placement of government revenue or the PAD.

The CAR variable is negatively associated with the lending of the BPD. This indicates that an increasing CAR ratio will reduce the amount of BPD lending in a region. The results are consistent with the research conducted by Anindita (2011), Giovanny (2014) and Pratama (2010), which state that the CAR negatively and significantly influences bank lending.

A greater CAR ratio owned by a bank is a signal of its efforts to strengthen capital (Anindita, 2011). The BPD has the same character as other commercial banks in Indonesia, in that when CAR is produced the amount of credit will be reduced by the BPD. Thus, the determination of the size of the CAR must be adapted to the conditions of the BPD because it relates to the capital owned by the BPD.

The NPL variable is negatively associated with BPD lending. This indicates that an increase in the NPL ratio will reduce the amount of BPD lending in the region. The results are consistent with the results of research conducted by Mukhlis (2011) and Pratama (2010), which state that the NPL negatively and significantly influences bank lending. This result does not correspond with the research of Yoga and Yuliarmi (2013) and Trimulyanti (2013), which state that the NPL has no significant effect on bank lending.

Variable size is positively related to BPD lending. This indicates that increasing the size of a BPD will increase the amount of BPD lending in the region. This is consistent with the results of research conducted by Tomak (2013), which states that size has a positive effect on the bank lending rate. The study mentioned that government-owned banks located in developing countries, which, in general, are larger in size, have a better ability to access long-term financing.

The lending rate variable is negatively related to the BPD lending. This indicates that an increase in the lending rates of the BPD will reduce the amount of BPD lending in the region. This is consistent with the results of research conducted by Anindita (2011) and Tyastika (2013), which state that the lending rate has a significant negative effect on bank lending. However, it is not compatible with Yoga and Yuliarmi's findings (2013), which state that the lending rates do not significantly affect the increase in the bank credit channel. 


\subsection{Equation model (2)}

In the equation model (2), the distribution of productive credit is influenced by variables such as the following:

The GRDP variable is positively related to BPD productive lending. The increase of GRDP is a picture of a region's success in managing its economic resources. This then stimulates the BPD to lend in regions that have good economic conditions. Therefore, this implies that the larger the GRDP generated by a region, the greater the potential for the BPD to distribute productive lending.

The CAR variable is negatively related to BPD productive lending. This indicates that an increase in CAR ratio will reduce the amount of BPD productive lending in the region. Thus, the determination of the size of the CAR must be adapted to the BPD conditions because it relates to capital owned by the BPD, given that the primary function of the BPD, similar to that of other banks, is to channel the funds that have been collected, primarily for the development of the growth of the productive sector.

The DPK variable is positively related to BPD productive lending. This indicates that an increase in the deposits of the BPD will increase the amount of BPD productive lending in the region. The results are consistent with the research conducted by Pratama (2010) and Oka et al. (2015), which state that the DPK significantly and positively influences bank lending.

In the productive lending portfolio, the BPDs also use funds from DPK. The funds raised from the public are used as the operating capital of the bank (Oka et al., 2015). The availability of these funds will affect the level of the productive lending portfolio of the BPD, since productive lending is the priority for the BPD in order to help local development.

The productive sector in Indonesia, especially SMEs, have still not been funded because of the uncertainty of future financial conditions. Therefore, the BPD needs to raise more capital for productive lending and bear all the risks related to the loan portfolio.

Variable size is positively related to BPD productive lending. This indicates that increasing the size of a BPD will increase the amount of BPD productive lending in the region. Tomak (2013) states that size has positive effects on the bank lending rate. The study mentions that the government-owned banks that are located in developing countries are, in general, of a larger size because of a better ability to access long-term financing.

\section{CONCLUSION}

According to the results, BPD lending is significantly influenced by non-oil and gas imports, PAD, CAR, NPL, size and lending rates. PAD and size positively influence BPD lending, which indicates that an increase of PAD and size will affect the increase in BPD lending. On the other hand, non-oil and gas imports, CAR, NPL and lending rates have a negative effect on BPD lending. Increasing one, or all, of them will lead to a decrease in BPD lending.

In the next research, we found that BPD productive lending is significantly influenced by two factors, namely the CAR and size. The availability of capital and the size of banks are the main factors that causes BPD productive lending to fluctuate. The establishment of the BPD to move funds in the form of credit, especially for the productive sector, is only visible if the BPD has a strong amount of capital.

In order to increase financing in the productive sector, the BPD is expected to have invested sufficient capital in the certain level of risk taking in the existing productive sector. Poor credit, which could be experienced due to the cessation of production processes, disturbs BPD fund distribution in the form of credit.

In addition, the BPD could also be reluctant to distribute lending because of limited amounts of savings. In other words, the BPD still relies on deposits from the local government. The savings will be reflected in the size of each BPD. This is due to the fact that the ability of the BPD to access long-term funding is affected by the amount placed by the local governments through local revenue. 


\section{REFERENCES}

Agustine, A.M. (2009). Analysis the influence of internal and external factors of banking on lending of small and medium business (Case of Bank in period 2007-2008) (Master's thesis). University of Indonesia.

Anindita, I. (2011). Analysis the influence of interest rate, car, npl, and ldr on lending of small and medium enterprises (Study case of private bank in the period of 2003-2010) (Master's thesis). University of Diponegoro.

Giovanny, A. (2014). Analysis the impact of deposits, capital adequacy ratio, nonperforming loan, loan to deposit ratio, and return on asset lending of regional development bank in Indonesia (Master's thesis). University of Sumatera Utara.

Guizani, B. (2014). Capital requirements, banking supervision and lending behavior: Evidence from Tunisia. Munich Personal RePEc Archive. https://mpra.ub.uni-muenchen.de/54234/1/MPRA_ paper_54234.pdf.

Indiapsari, P. (2012). The effect of liquidity, Assets Quality, Market Sensitivity, Efficiency and Profitability to Capital Adequacy Ratio (CAR) of Listed Banks in Indonesia (thesis). STIE Perbanas.

Indonesian Banking Booklet (2014). "Development and Banking Policy" Jakarta: Indonesia financial services authority. http://www.bi.go.id/id/publikasi/perbankan-dan-stabilitas/booklet-bi/Default. aspx.

Meydianawathi, L.G. (2007). Analysis the lending behavior of banking to small and medium business in Indonesia in the period 2002-2006. Buletin Studi Ekonomi, 12(2).

Mukhlis, I. (2011). Lending behaviour: the role of third-party funding and non-performing loans. Jurnal Keuangan dan Perbankan, 15(1), 130-38.

Oka, K.W.L., Purnamawati, G.A. \& Sinarwati, N.K. (2015). The impact of deposits, 5Cs valuation, and lending quality in lending decision of regional development bank in Bali, branch of Singaraja,. e-Journal S1 Ak Universitas Pendidikan Ganesha, Jurusan Akuntansi Program S1, 3(1).

Olusanya, S.O., Oluwatosin, O.A. \& Chukwuemeka, O.E. (2012). Determinants of lending behavior of commercial banks: Evidence from Nigeria, a co-integration analysis (1975-2010). IOSR Journal of Humanities and Social Science, 5(5), 71-80.

Pangastuti, Y. (2015). Analysis determinants of employment in central java in 2008-2012.. Economics Development Analysis Journal, 4(2), 224-34.

Parwito (2015). Fiscal system make regional fund become idle. http://www.unisosdem.org/article_detail. php?aid $=6560 \&$ coid $=2 \&$ caid $=30$.

Pratama, B.A. (2010). Analysis determinants affecting lending decision of banking (study case of Indonesian commercial bank in year 2005-2009) (Master's thesis). University of Diponegoro.

Rokhim, R. (2007). Regional fund optimalization. Bisnis Indonesia. Retrieved May 20, 2016, from http:// www.unisosdem.org/article_fullversion.php?aid $=7456 \&$ coid $=1 \&$ cai d $=26 \&$ gid $=2$.

Tomak, S. (2013). Determinants of commercial banks' lending behavior: Evidence from Turkey. Asian Journal of Empirical Research, 3(8), 933-43.

Triandaru, S. \& Budisantoso, T. (2008). Bank and non-bank financial institutions. Jakarta: Salemba Empat.

Trimulyanti, I. (2013). Analysis internal factors on lending growth (case study of rural bank in Semarang city in year 2009-2012) (Master's thesis). Universitas Dian Nuswantoro.

Tyastika, M. (2013). Analysis he impact of microeconomic performance and macroeconomic factors on farming lending (case study of regional development bank in Indonesia) (Master's thesis). Bogor Agricultural University.

Wicaksono, B. (2004). Analysis the behaviour of banking lending in terms of intermediation function (case study of Jakarta, west java, east java, and west sumatera) (Master's thesis). University of Indonesia.

Yoga, G.A.D.M. \& Yuliarmi, N.N. (2013). Determinants affecting banking lending in Rural bank in Bali province. E-Jurnal Ekonomi Pembangunan Universitas Udayana, 2(6), 284-93.

Yuwono, T. \& Warsito. (2001). Regional autonomy management. Semarang: CLoGAPPS, Universitas Diponegoro. 


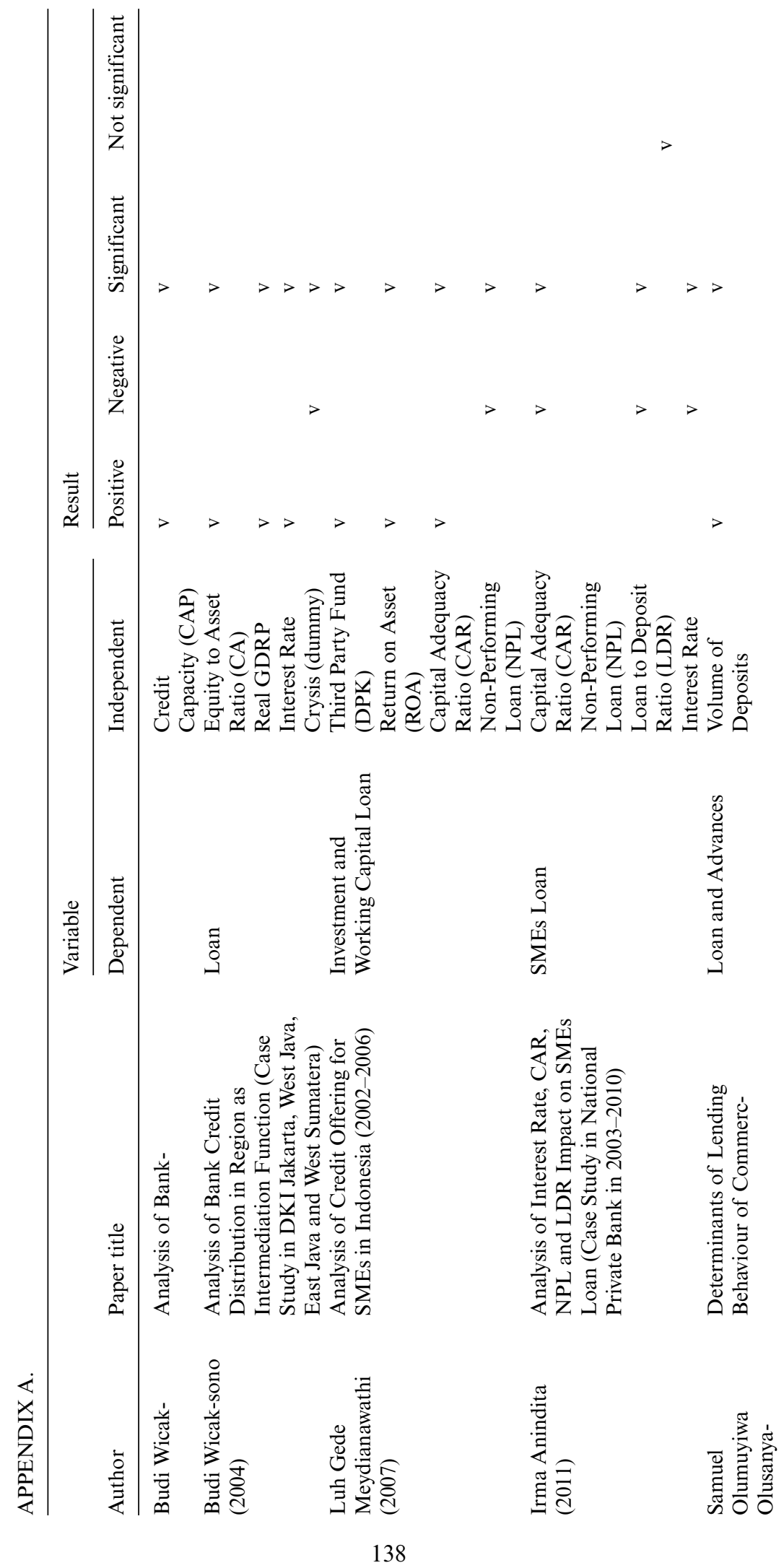




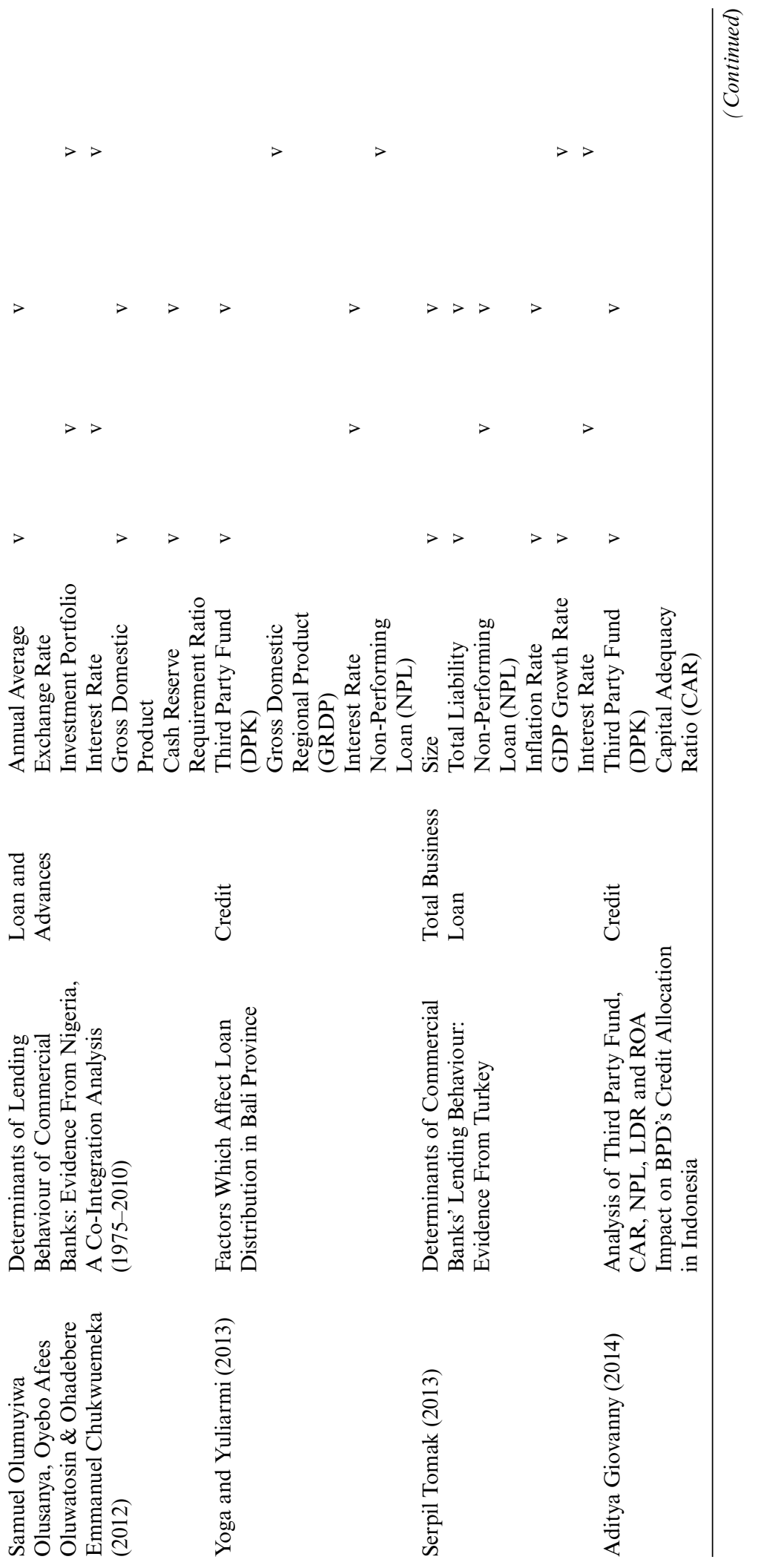




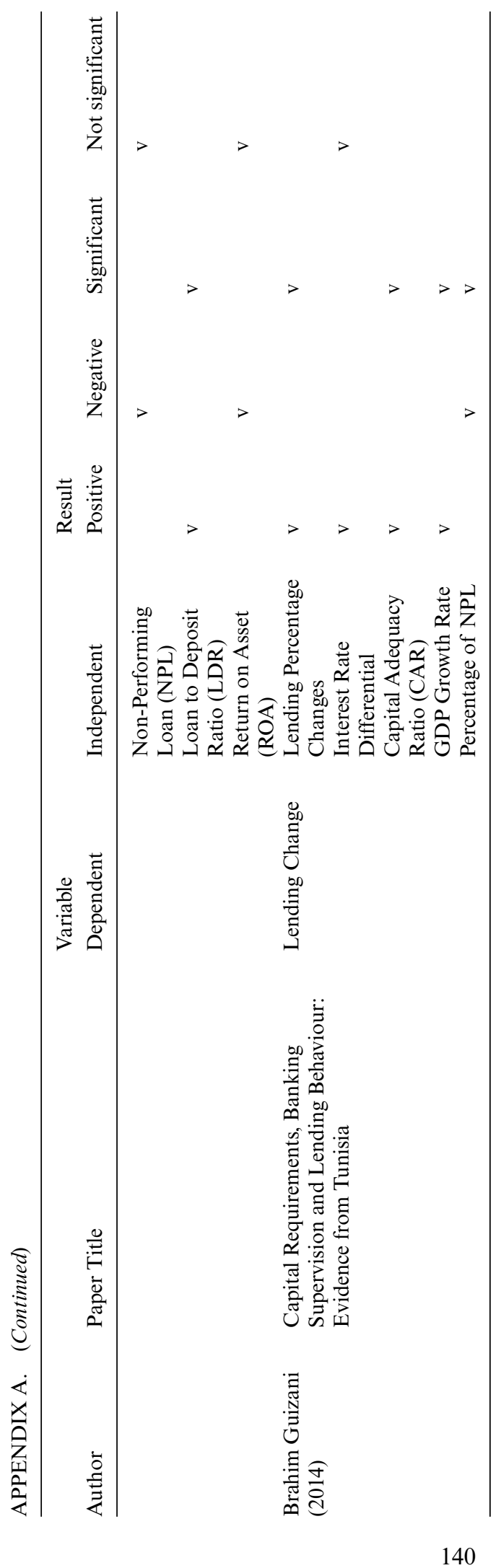

